\title{
Development of Batik Motif Barrau Cawul
}

\author{
Suparmi \\ Student of Program Pascasaejana, Universitas Negeri \\ Yogyakarta. \\ Kampus Karangmalang Yogyakarta, 55281 \\ Yogyakarta, Indonesia \\ 11703261004@ student.uny.ac.id
}

\author{
Purwono \\ Inspektoran Kabupaten Berau \\ Jalan SM Aminudin No.1012 Tanjungredeb, Berau \\ Tanjungredeb, Indonesia \\ purwonoipoeng@gmail.com
}

\author{
Rita Artuti \\ Independent designer \\ Ngruki, Solo \\ Surakarta, Indonesia \\ ritaartuti@gmail.com
}

\begin{abstract}
This study aims to develop Batik motif Barrau Cawul. The source of inspiration is taken from the local cultural arts ornaments. The research and development was designed. There are three stages in this research: exploration, design, and realization. Naming Batik motif of Barrau Cawul based on Focus Group Discussion. The Result of Barrau Cawul Batik produce three motifs as follows: Busak Kangkung Balilit Motif; Busak Kangkung Sarayak Motif; Busak Kangkung Taggu Motif. Berau has batik with characteristic of local motif and can improve people's prosperity
\end{abstract}

Keywords-Cawul Batik; Balilit; Sarayak; Taggu.

\section{INTRODUCTION}

This research is a continuation of prasurvey of local cultural excavation to find the meaning of ornament of ancestral heritage in the Gunung Tabur palace and Sambaliung palace in Berau regency of East Kalimantan. The results obtained are the values contained in accordance with the character of the Indonesian nation. For that need to be maintained and preserved. Efforts are made by implementing the motif of ornamental decoration into batik motifs. The spirit of maintaining and preserving the motif of ornament into batik is in line with the determination of United Nations Educational, Scientific, and Cultural Organization (UNESCO), batik as a Masterpieces of the Oral and Intangible Heritage of Humanity since October 2, 2009 [1]

Exploration of the noble wealth of the nation's culture needs to be done, as well as criticizing its existence associated with the inevitability of cultural change. Local excellence is a human wisdom that rests on a traditional philosophy of values, ethics, ways and behaviors that are traditionally. Ancestral culture as local wisdom is a value that is considered good and right so it can survive for a long time and even institutionalized [2].

Barrau Cawul batik was originally created as an effort to reinforce the city identity. Berau district to date in sufficient clothing still bring from the Java island. With the background is required development of batik motifs. The development of the motifs aims to maintain and preserve the local characteristic culture and also provide for the needs of clothing for the peoples of Berau district. To maintained and preserved the art of crafts can be to include materials in the local content curriculum in formal schools from kindergarten to high school levels. Batik production can also be done in the district of Berau and has a positive effect on the economy and prosperity of Berau peoples.

\section{LITERATURE REVIEW}

Plant as the determining factor of the continuity of the survival of other beings, its role is quite large in filling the journey of human culture. Different ways of express love with symbol of human feeling towards something great. Disclosure of feelings and emotions is reflected in works, such as symbolic representations that visualize a particular meaning, and its basic reprenentation alone without symbols and only make surface objects [3].

Batik culture is the process of producing something. [4] Batik is a technique in the process of decorating the textile surface by holding the dye. [5], Batik is painting or drawing on mori fabric with canting technique. [6] Batik is a textile fabrics dyeing, dyeing according to the characteristic feature of batik Indonesia, using batik wax as a barrier. Batik produces batik cloth with various motifs and has special properties that have batik.

[7] There are three main batik techniques: Hand-waxed (hand-drawn), Hand-stamped, Combination of the two. The hand-waxed batik or hand drawn Batik (Batik Tulis) is produced by painting the wax on the cloth using a traditional tool called the canting. The hand-stamped Batik is produced by stamping the wax on the cloth using a copper stamp to make the Batik design. The other technique combines both the 
canting and the stamp in order to produce more creative designs.

[7] Influence of modern technology is the production of batik textile which is the printing of Batik designs on cotton or synthetic fabrics using modern machinery. As a result, the process is quick, low cost and easy to produce; however, mass production cannot produce quality art. There is the term batik printing or screen printing in the process of this batik, the pattern has been printed on a screen printing tool, so that batik and staining are usually done directly. So, batik process can be solved without using candle night and canting. Thus, the process will only and of course require a faster time compared to the process of hand drawn batik and batik cap. Price is relatively cheaper than both types of batik above, due to faster processing time and mass produced or in large quantities. Batik printing does not include the traditional batik line, due to not wearing the wax, but batik printing into the ranks of "Textile Batik motif"

Motifs are often inspired from nature and are also closely linked to natural, cultural, religious and socio-economic factors prevailing in any society.Motif is something that became the base of the theme consisting of several elements of form or object, scale or proportion, and composition. The motif is applied in a repeated manner to obtain a pattern. Patterns then made into an ornament. Batik motif is a picture on batik which is a combination of lines, shapes, and isen into a unity that forms a mere unity. Batik motif is also called batik patterns [8]. So batik motif is the result of ornament application in a series of batik process. The creators of batik motifs in ancient times not only created something beautiful, but also gave meaning related to the philosophy of life with the message and hope to bring goodness and happiness to the wearer.

Local knowledge is developed on the basis of experience as it has been tested after being adapted to the local culture and environment, and is dynamic and changing. Local wisdom is the truth that has been a tradition in a region and a combination of the holy values of the word of God and the various values that exist in society [9]. One effort to get to know more about the philosophy of the nation is to learn the way of life of society from the repertoire of local culture/customs [10].

Batik is a decorative application for something wearing objects as a clothing (make up) in order to get the beauty or elegance that combined. [3] Wearing goods is anything that man creates in the form of material product to meet the needs, with the utility consideration, the selection of materials, the process of making to the pleasure of the wearer. [5] The creators of ancient batik motifs include the beauty, giving meaning to the philosophy of life, the noble message and the sincere hope of bringing goodness and happiness to the wearer. (11), the beauty of batik motif lies in two things, namely: visual beauty is obtained from harmonious blend of color and form; Spiritual beauty is derived from the philosophy of symbols of form and color corresponding to understandable understandings.. Development of Barrau Cawul batik to produce visual and spiritual beauty.

\section{METHODS}

The Research and Developpment (R \& D) method of crafts was used according to [12] through three stages of exploration, design and embodiment stage.

Exploration stage is the activity of soul wandering and the development of the source of ideas by exploring the sources of ideas such as visual in the Gunung Tabur Palace, Sambaliung Palace and custom house, by collecting references and drawings related to the works. Interviews were also conducted for indigenous community leaders and members of the family of Gunung Tabur palace and Sambaliung palace in Berau, East Kalimantan, Indonesia. Exploration was conducted in 2009.

At the design stage is done muse over ideas the results of the analysis. The elements of design batik motif is done and discuss by the team of authors and in the final process through the validation of traditional figures and stakeholders Berau district. The resulting validation process will then be realized in the form of design or working drawings, and will become a form of work.

The realization stage is realizing ideas, concepts, foundations, and concepts into works. The work of batik products cooperate with home factories in Solo, Central Java. Evaluation to look thoroughly at the appropriateness between the idea and the creation and also criticize the quality of the fisical/textual artwork by socializing several community leaders. Evaluation in terms of meaning adjusted with local cultural excavation by the author. Giving of the name product by Focus Group Discussion (FGD).

\section{RESULTS}

Research on the development of batik design motif Barrau Cawul has produced three new batik motifs that have characteristic areas of the Barrau society. The three motifs are a combination of several elements of ornamental motifs of busak kangkung and busak ubi rambat that both have similar characters. Busak kangkung is kangkung flower Ipomoea fistulosa spesies, Convolvulaceae family and busak ubi rambat is yam flower. Green turtle and swallow bird as an asset of Berau district area also applied to batik motif. Element motif tali gumali is a symbol of youth fraternity and parang motif element from Java also applied because there is acculturation of culture of Barrau and Java society with the occurrence of marriage of King Gunung Tabur with female of Java. The background color matches the distinctive colors of the Barrau society, namely Yellow. For product development, all motifs are used in yellow, blue, purple, green, pink. 
TABLE I. MOTIF EXPLORATION

Figure

The FGD was conducted to give name for Barrau Cawul Batik and three new batik motifs. The meaning of Cawul is fabric pictorial or striped. FGD conducted on November 10, 2010 led by Mr. Ir. Soeparno Kasim, Assistant III of Berau District Head. FGD participants included representatives from cultural institutions in Berau district and family from the palace of Gunung Tabur and Sambaliung, as well as Berau cultural arts community. Barrau Cawul Batik was launched on November 13, 2010 with three motifs as follows:

\section{A. Busak kangkung balilit motif}

The motif element consists of busak kangkung and green turtle. The meaning embodied in this motif is the wearer is expected to united, innovate in achieving common goals, have humility, easy to adapt to the environment dynamic, religious society, long life, and bring the beauty of the fragrance of his name.

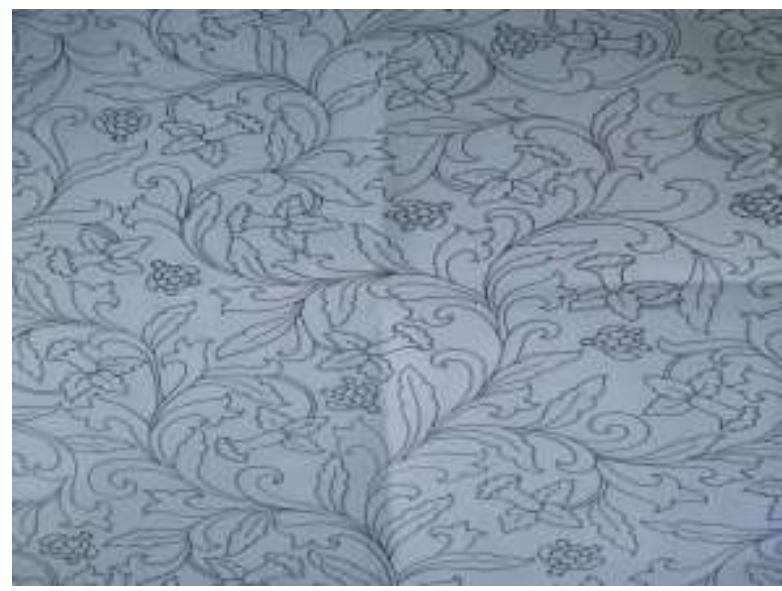

Fig. 5. Busak kangkung balilit motif

\section{B. Busak kangkung sarayak motif}

The motif element consists of: busak kangkung, rhombus square box, Green Turtle and Swallow bird. The meaning contained in this motif is the wearer mutual respect each other, can united in the effort to achieve prosperity together, wellbeing, long life and bring the beauty of the fragrance of his name.

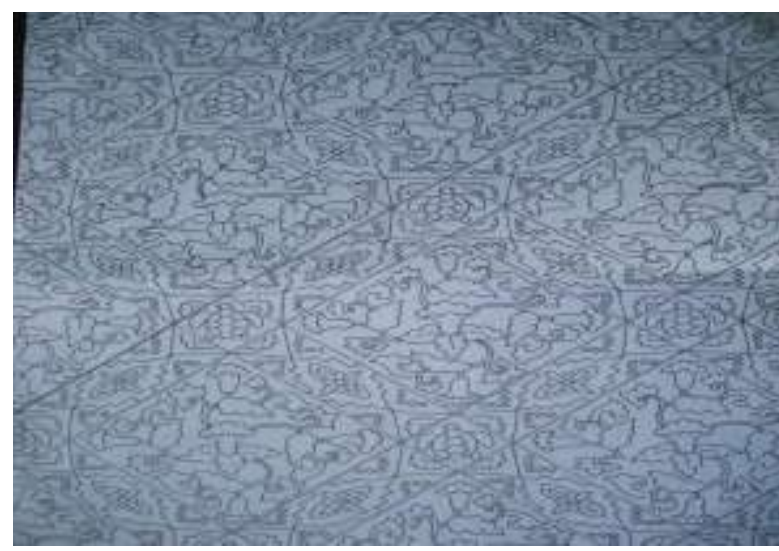

Fig. 6. Busak kangkung sarayak motif

\section{Busak kangkung taggu motif.}

The motif elements consist of: (a) busak kangkung, green turtle, swallow bird and parang; (b), busak kangkung, tali gumali, and green turtle. This motif is acculturation with Javanese culture. The meaning embodied is expected to have the wearer of power, glory, dignity, firmness, can protect others to face life to succeed because of the bridges of brotherhood, long life, bringing the beauty of the fragrance of his name. 


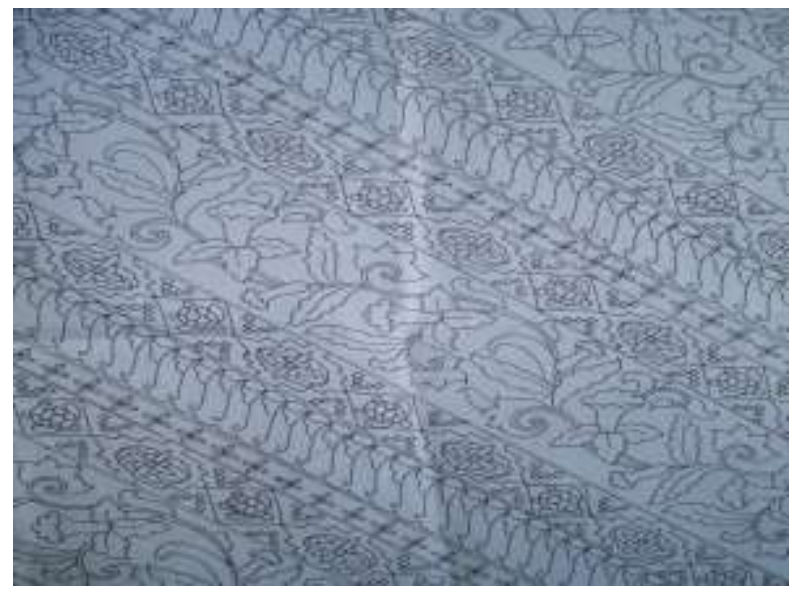

Fig. 7. Busak kangkung Taggu motif

Production while still using printing to meet market needs. The production process of barau cawul batik is still in collaboration with home-grown in Solo, central java. Production can not be done in Berau because local human resources are not yet competent.

\section{DISCUSSION}

The Barrau society learned the life of the busak kangkung and the busak ubi rambat as the original nature of the plant (3). The busak kangkung means that life must be strong to adapt in any nature, as a form of gratitude to God Almighty. Scented the yam rot is interpreted as a convenience and survives close to anyone, not arrogant and beneficial to others. The Barrau society are friendly, not arrogant, familiar and open to immigrants regardless of where they come from. The Barrau society can live in harmony with the environment despite the challenges. As long as the sun is shining they will endure by always putting their trust in God Almighty. Green turtle interpreted human have to live healthy in order to live long and in life to travel far but still return in season. Swallow birds interpreted that the best humans can produce something useful for other human life (9), (10).

Barrau Cawul Batik is a way to decorate fabric with various images/patterns (5), (6), (4). Developing of Barrau cawul batik motifs produce three motifs that generate visual beauty and spiritual beauty. The visual beauty with a harmonious blend of decorative shapes and bright colors. The spiritual beauty that is contained in the values of the life of the Barrau society is hardworking, tenacious, humble, steadfast and able to adjust in life. Life that is beneficial to others, friendly, togetherness, happy life to live longer, religious although many obstacles in life away from their crowd still exist because God Almighty who has given life. (11), (5).

\section{RECOMMENDATION}

Cultural arts preservation can be incorporated into the formal school curriculum as local content ranging from kindergarten through high school. Until now Barrau Cawul batik products are still done by home factories in the city of Solo, Central Java. The abundant human and natural resources preparedness is needed to produce batik Barrau Cawul in Berau district which has a positive effect on the economy and prosperity of Berau peoples. There are still many symbols of local decoration, in the future excavation and development still needs to be done.

\section{CONCLUSION}

These three motifs show that the Barrau society are the people who always uphold the cultural values, namely: remember and give thanks to God Almighty, hardworking, friendly, familier, uphold together, tie brotherhood, open to immigrants, peace loving, not arrogant, Simple, generous, and virtuous and noble

\section{ACKNOWLEDGMENT}

Pemerintah Kabupaten Berau, Ir. Suparno Kasim-assistant III of Kabupaten Beru; Hj. Dra. Rohaini, M.M., M.Pd.-Head of Dinas Pendidikan Berau; Princess and family Gunung Tabur Palace and Sambaliung Palace; H. Abdullah craftman Carving Berau.

\section{References}

[1] Haran Kompas Online, Batik Akhirnya Resmi Masuk Daftar Warisan UNESCO, (2009). http://nasional.kompas.com/read/2009/10/01/1949569/Batik.Ak hirnya.Resmi.Masuk.Daftar.Warisan.UNESCO download Januari 22, 2010.

[2] Sartini, Menggali Kearifan Lokal .Jurnal Filsafat, Augus, Vol. 37, No. 2, (2004).

[3] Toekio M., Soegeng, Mengenal Ragam Hias Indonesia. Bandung: Angkasa, (2000).

[4] Tirta, Iwan, Batik Sebuah Lakon. Jakarta : Gaya Favorit Press (2009).

[5] Djoemena, Nian S. (1990). Ungkapan Sehelai Batik: Its Mystery and Meaning. Jakarta: Djambatan (1990).

[6] Soesanto, Sewan, Seni dan Teknologi Kerajinan Batik. Departemen.Perindustrian RI (1992).

[7] TREDA, Ministry of Trade of The Republic of Indonesia. Indonesia Batik: A culture beauty (2008)

[8] Susanto, S, Seni Kerajinan Batik Indonesia. Yogyakarta: Balai Penelitian Batik dan Kerajinan (1980)

[9] Gobyah, Berpijak pada Kearifan Lokal. (2008). http://www.balipos.co.id/berpijak_pada_kearifan_lokal.2008.upload.pdf

[10] Pramono, Unsur-Unsur Filsafat Indonesia. Yogyakarta: Andi Offset (1985).

[11] Soesanto, Sewan. Seni Kerajinan Batik Indonesia. Yogayakarta: BPKB (1973).

[12] Gustami, S.P., Butir-Butir Mutiara Estetika Timur, Ide Dasar Penciptaan Karya Seni Kriya Indonesia. Yogyakarta: Prasista (2007). 